\title{
Julia Dynkowska*
}

iD https://orcid.org/0000-0001-7657-2679

\section{"Jak żywa" to uniwersalny komunat? \\ O nieoczywistych związkach prozopopei z ekfrazą w powieści Portret Pierre'a Assouline'a}

\section{Streszczenie}

Ekfraza - literacka deskrypcja dzieła sztuki - nie jest, rzecz jasna, wyłącznie dokładnym opisem artefaktu; często dotyczy również tego, czego na obrazie nie ma. W ekfrazach dzieła sztuki ulegają czasem swoistemu „ożywieniu” - narratywizacji namalowanych scen, a także uzupełnieniu ich o przed- i „poakcje” czy też o wyobrażone wypowiedzi przedstawionych postaci. Artykuł dotyczy specyficznej formy takich literackich „ożywień”, czyli tekstów, których autorzy, wykorzystując prozopopeję, oddali głos bohaterom obrazów oraz świadomym swej sztuczności (i eksponującym ją) obrazom-przedmiotom. Ciekawym (i rozbudowanym) przykładem zastosowania prozopopei jest powieść Portret P. Assouline’a. Narrację prowadzi w niej namalowana przez J.A.D. Ingres'a Betty de Rothschild. W artykule omawiam sposób i sens zastosowania tej figury retorycznej w powieści Assouline’a i zastanawiam się nad tym, czy każdy tekst literacki, w którym narratorem (dzięki prozopopei) czyni się postać z obrazu, można nazwać ekfrazą.

Słowa kluczowe: intertekstualność, intersemiotyczność, prozopopeja, ekfraza, apokryf, sztuka, Jean-Pierre Assouline, Auguste-Dominique Ingres

* Dr, Uniwersytet Łódzki, Wydział Filologiczny, Instytut Kultury Współczesnej, Katedra Teorii Literatury, ul. Pomorska 171/173, 90-236 Łódź; e-mail: julia.dynkowska@uni.lodz.pl 
W eseju Obrazy i portrety Virginia Woolf zauważa:

Nikomu o rozwiniętym zmyśle plastycznym nie przyszłoby nigdy do głowy, by pomyśleć o obrazach jako o sztuce niemej. W tym jednak przekonaniu tkwią korzenie zwyczajnej u Anglików odrazy do obrazów. Wiszą oto, jakby upływ wieków nie miał dla nich znaczenia. W osobistym utrapieniu czy publicznej katastrofie nie wydusimy z nich żadnego przesłania. Co takiego widzą, spoglądając w głąb pokoju - nie mam pewności: może jakąś wenecką gondolę sprzed kilkuset lat ${ }^{1}$.

Mimo wszystko wielu twórców stara się - co też Woolf postuluje - „zaspokoić swoją fantazję", czyli spojrzeć na świat z pespektywy obrazów, oddając głos bohaterom dzieł sztuki oraz samym obrazom-przedmiotom, a zatem: posługując się prozopopeją. Właśnie takim, wykorzystującym tę figurę retoryczną, tekstom chciałabym przyjrzeć się w moim artykule. Prozopopeję (od prósopon poiéin, czyli „przydawać maskę lub oblicze”, „tworzyć postać”; prósopon - „twarz”, „oblicze”, „maska”, „mina”, „wyraz twarzy”, „osoba”), definiowaną jako „wprowadzenie nieosobowych obiektów [również osób zmarłych] jako osób posiadających zdolność mowy i inne formy ludzkiego zachowania", Heinrich Lausberg uznaje za „najmocniejszą figurę emotywną utworzoną przez wyolbrzymienie mentalnej kreatywności”' Jak pisze bowiem Marta Tomczok,

[d]zięki niej możemy obcować nie tylko z tymi, którzy są i do nas mówią, lecz także z tymi, o których myślimy, że chcieliby z nami rozmawiać, chociaż ich nie ma lub są niesłyszalni: ze zmarłymi, niemowami, niemowlętami, a nawet roślinami, zwierzętami, rzeczami, ideami $[\ldots]^{6}$.

1 W. Woolf, Obrazy i portrety, w: tejże, Eseje wybrane, przeł. M. Heydel, Karakter, Kraków 2015, S. 193.

2 P. de Man, Autobiografia jako odtwarzanie, przeł. M.B. Fedewicz, „Pamiętnik Literacki” 1986, z. 2, s. 314 .

3 Progymnasmata. Greckie ćwiczenia retoryczne i ich modelowe opracowanie, oprac., przeł. i koment. H. Podbielski, Towarzystwo Naukowe Katolickiego Uniwersytetu Lubelskiego Jana Pawła II, Lublin 2013, s. 99.

4 M. Tomczok, Prozopopeja, w: llustrowany słownik terminów literackich. Historia, anegdota, etymologia, pod red. Z. Kadłubka, B. Mytych-Forajter i A. Nawareckiego, Słowo/Obraz Terytoria, Gdańsk 2018, s. 394.

$5 \quad$ H. Lausberg, §826, w: tegoż, Retoryka literacka. Podstawy wiedzy o literaturze, przeł. oprac. i wstęp A. Gorzkowski, Homo Homini, Bydgoszcz 2002, s. 454.

6 M. Tomczok, dz. cyt., s. 395. Badaczka zwraca również uwagę na to, że w starożytności znaczenie prozopopei było ograniczone do „cytatu będącego naśladowaniem cudzej mowy w obrębie własnej”, a zatem rodzajem mikrostylizacji, mikropastiszu. 
Właśnie ze względu na możliwość twórczego obdarzania głosem milczących obiektów, prozopopeję łączy się niekiedy z ekfrazą, czyli - według dość pojemnej definicji autorstwa Pawła Goglera - „utworem lub fragmentem utworu (poetyckiego, prozatorskiego, dramatycznego), będącym dokładnym, ozdobnym opisem lub zawierającą elementy opisu interpretacją (przetworzeniem, transpozycją) dzieła sztuki malarskiej (rzeźbiarskiej, architektonicznej, fotograficznej), które to dzieło może istnieć bądź nie istnieć”" Najczęściej w kontekście powiązania prozopopei i literackich deskrypcji dzieł plastycznych pisze się o Jeanie Hagstrumie i jego restrykcyjnej koncepcji tej drugiej kategorii. Zdaniem Hagstruma ekfrazami można nazwać tylko te teksty, w których niemy obiekt artystyczny uzyskuje głos ${ }^{8}$. To oczywiście dość skrajne ujęcie; w innych opracowaniach „prozopopeja” w kontekście ekfrazy metaforyzuje literacki sposób radzenia sobie z milczeniem obrazu. Taka perspektywa wiąże się często, po pierwsze, z odniesieniem do etymologii terminu ekphrasis (od ekphrázo, czyli m.in. „wypowiadać””, „opowiadać”, ekphrazein - „wypowiedzieć w całości”作), po drugie zaś - z, nieco już nieaktualnym, pojmowaniem ekfrazy jako swoistej odpowiedzi na przywoływane przez Plutarcha zdanie Simonidesa z Keos: malarstwo to milcząca poezja, a poezja to mówiące malarstwo"1. Jak pisze Valentine Cunningham:

7 P. Gogler, Kłopoty z ekfraza, „Przestrzenie Teorii” 2004, z. 3-4, s. 141. Decyduję się na zacytowanie sformułowania Goglera, ponieważ w przeciwieństwie do klasycznych definicji (np. tej najczęściej cytowanej autorstwa Jamesa A.W. Heffernana: ekfraza to „werbalna reprezentacja reprezentacji wizualnej") akcentuje najważniejszą - w moim przekonaniu - z cech ekfrazy, a mianowicie jej interpretacyjny charakter. J.A.W. Heffernan, Museum of Words. The Poetics of Ekphrasis from Homer to Ashbery, University of Chicago Press, Chicago 1993, s. 3. Pierwiastek interpretacyjny literackich deskrypcji dzieł sztuki akcentują również m.in. Jaś Elsner oraz Shadi Bartsch (zob. S. Bartsch, J. Elsner, Eight Ways of Looking at an Ekphrasis, „Classical Philology” $2007 \mathrm{nr}$ 1, s. ii).

8 O Hagstrumie w tym kontekście wspominają m.in. Bartosz Swoboda (B. Swoboda, Ekfrazy modernistyczne i „mowa dzieła sztuki”, „Slovo. Journal of Slavic Languages, Literatures and Cultures" 2015, nr 56, s. 90) i Dobrawa Lisak-Gębala. D. Lisak-Gębala, Ultraliteratura. O strategiach transmedialnych i poszukiwaniu pozawerbalnego we współczesnej literaturze polskiej, Universitas, Kraków 2014, s. 42. Badaczka wykorzystuje zresztą również rozpoznania Paula de Mana dotyczące prozopopei, wiążąc je z ekfrazami fotograficznymi. Zob. J.H. Hagstrum, The Sister Arts: The Tradition of Literary Pictorialism and English Poetry From Dryden to Gray, University of Chicago Press, Chicago 1958, s. 18-29.

9 R. Popowski, Starożytny przewodnik po neapolitańskiej pinakotece, w: Filostrat Starszy, Obrazy, przeł. i wstęp R. Popowski, Prószyński i S-ka, Warszawa 2004, s. 33. Zob. też R. Webb, Ekphrasis Ancient and the Modern: The Invention of a Genre, "Word and Image” 1999, t. 15, nr 1, s. 7.

10 J.W. Heffernan, Ekphrasis and Representation, „New Literary History” 1991, nr 2, s. 302.

11 Nad autorstwem, dosłownym brzmieniem i znaczeniem tego wielokrotnie przywoływanego zdania zastanawia się m.in. Krystyna Bartol. Por. K. Bartol, Poezja - malarstwo. Plutarch o słynnym powiedzeniu Simonidesa, „Roczniki Humanistyczne” 2006-2007, z. 3, s. 107-118. 
Ekfraza [...], pozwala zamanifestować towarzyszące literaturze od zawsze pragnienie wskrzeszania - chęć przywrócenia życia i głosu przeszłości. Najstarsze dzieła znów stają się słyszalne, wydobyte z ciszy przeszłości: i historycznej, i tekstowej (?). Głos zostaje udzielony niemym przedmiotom w akcie ekphrasis, dosłownie 'wy-powiadania się, $[\ldots]^{12}$.

Uwagi Cunninghama pozwalają również dostrzec podwójny status prozopopei: $\mathrm{z}$ jednej strony to figura o emancypacyjnych, w pewnym sensie, właściwościach ${ }^{13}$, umożliwia bowiem zabranie głosu tym, którzy nie mieli go wcześniej, z drugiej zaś - jej warunkiem jest właśnie owo wstępne milczenie ${ }^{14}$.

Utwory, których autorzy posłużyli się prozopopeją to również specyficzna forma literackich „ożywień” w ekfrazie. „Ożywienia” w literackich deskrypcjach dzieł sztuki polegają na narratywizacji namalowanych czy sfotografowanych scen, uzupełnianiu ich o przed- i „poakcje” oraz o wypowiedzi przedstawionych postaci. Dobrawa Lisak-Gębala zauważa, że tego typu zabiegi to efekt „[...] myślenia o ekfrazie właściwego najdawniejszej jej tradycji (reprezentowanej przez retoryczne ${ }^{15}$ progymnasmata i Obrazy Filostrata Starszego), która uprzywilejowywała chwyty obdarowujące obrazy pozorami życia"16. Zdaniem wrocławskiej badaczki owo „uprzywilejowanie” wynika z antycznego rozumienia deskrypcji i celu", jaki ma realizować ta figura retoryczna, czyli enargei/evidentii: „żywości przedstawienia”"18, usytuowania „słuchacza [opowieści] w pozycji naocznego świadka”19.

12 V. Cunningham, Why Ekphrasis?, "Classical Philology” 2007, nr 1, s. 63-64.

13 O takim kontekście - uzyskania możliwości wypowiedzenia swego, zwłaszcza kobiecego, traumatycznego doświadczenia w ekfrazie - pisze Bartosz Swoboda (dz. cyt.), powołując się na ustalenia W.J.T. Mitchella i J. Heffernana, odnoszące się do stereotypowego przypisania oglądanemu, zatem biernemu, obrazowi cech żeńskich i oglądającemu, czyli aktywnemu, podmiotowi cech męskich.

14 Warto także odnotować, że niektórzy badacze doszukują się wspólnych korzeni ekfrazy i prozopopei w starożytnej retoryce. Jak bowiem pisze Remigiusz Popowski: „Być może pierwotnie ekfraza oznaczała retoryczną sztukę udzielania głosu niemym przedmiotom dla pobudzenia u słuchacza pełnej wyrazistości postrzegania lub - w przypadku opisu obrazu - dla ożywienia namalowanej sceny". R. Popowski, dz. cyt., s. 33.

15 H. Lausberg, Retoryka literacka..., s. 454.

16 D. Lisak-Gębala, Wizualne odskocznie. Wokół współczesnej eseistyki o malarstwie i fotografii, Universitas, Kraków 2016, s. 13.

17 Zob. H. Lausberg, dz. cyt., s. 573.

18 Tamże, s. 443.

19 Tamże. „Enargos” = „z całą wyrazistością” (Progymnasmata..., s. 281). Istotne jest także rozróżnienie enargei oraz energei, na które zwraca uwagę m.in. Albert Gorzkowski: „"enargeia" to jedna z figurae elocutionis, która zakłada zastosowanie w formie werbalnej naturalnej jakości obrazowania odniesionej do jakiegoś fragmentu rzeczywistości; »energeia« zaś to ogólnie virtus elocutionis, jeden ze sposobów deskrypcji rzeczywistości nadającej jej »żywość obrazu«, 
W związku z tym Lisak-Gębala włącza „ożywienia” (a w ich ramach również prozopopeje) do swojej definicji ekfrazy ${ }^{20}$, „za właściwą realizację tej figury” uznając

werbalizację malowidła bądź zdjęcia, posługującą się opisem odnoszącym się do oglądu konkretnego przedstawienia lub chwytami retorycznymi „ożywiającymi” zaprezentowany widok: dialogizacją (apostrofami, prozopopejami - w przypadku wizerunku osób) i narratywizacją (w przypadku obrazów ukazujących pewien zatrzymany etap ruchu), ale wyłącznie taką, która dopełnia przedstawioną scenę o jej bezpośrednią przedakcję lub bezpośrednią poakcję ${ }^{21}$.

Ekfrastyczne prozopopeje, czyli uzupełnianie dzieł sztuki o wyobrażone wypowiedzi przedstawionych postaci - to zabieg bardzo chętnie i często wykorzystywany przez twórców. Chyba najbardziej znanym przykładem takiego tekstu jest (przynajmniej w literaturze polskiej) Mozaika bizantyjska Wisławy Szymborskiej: dia$\log$ małżonków przedstawionych na tytułowym obrazie ${ }^{22}$. Na prawach prozopopei przemawiają też m.in. postaci z utworów Jacka Dehnela. Treścią jednego z nich jest monolog tytułowego bohatera Wskrzeszenia Łazarza, obrazu Sebastiano del Piombo. Łazarz z ironią opowiada tu o niedogodnościach trapiących go po zmartwychwstaniu: mimo ożywienia, nie przestał towarzyszyć mu odór nadpsutego ciała. Przez ten „drobiazg” jest stopniowo spychany na margines życia społecznego. W końcu zostaje zamknięty przez swoje siostry w odizolowanej izbie w ogrodzie, nazywanej ironicznie ,grobowcem”. Dehnelowskiego Łazarza, który po wskrzeszeniu nie jest już w stanie żyć w pełni, można potraktować jako synekdochę wszystkich postaci

aktualizującej tkwiącą w naturze i w res potencję dynamizmu oraz działania w ogóle" (A. Gorzkowski, „Ut pictura verba”: zagadnienie unaocznienia w retoryce starożytnej i wczesnonowożytnej, „Pamiętnik Literacki” 2001, nr 2 (92), s. 47); Christopher Collins pisze natomiast: „energia: the persuasive assertion by a speaker that he is presently imaging something, that he has been roused to action (has become energos) by a situation that the objective indices of gestures, intonations, and words demonstrate that he is now contemplating. Enargeia: the subjective act of imaging, the receptive state of potency that precedens the active (energic) response", Christopher Collins, Reading the Written Image. Verbal Play, Interpretation and the Roots of Iconophobia, The Pennsylvania State University Press, Pennsylvania 1991, s. 124. Lausberg odnotowuje jeszcze, że: „Praktyka deskrypcji służy figurze naoczności, evidentia [...], która obejmuje opis »kolektywnej konstrukcji wydarzeń (budowa miasta, zgiełk bitewny, sztorm na morzu, biesiady), który z kolei jako całość, przedstawia stan reszty opisywanego zdarzenia" (A. Lausberg, Retoryka literacka..., s. 573).

20 Warto odnotować, że badaczka w swoich pracach zajmuje się tekstami współczesnymi.

21 D. Lisak-Gębala, Wizualne odskocznie..., s. 13. Podkr. J.D.

22 Zob. M. Czermińska, Ekfrazy w poezji Wisławy Szymborskiej, „Teksty Drugie” 2003, nr 2-3, s. 237. 
z obrazów „ożywianych” w ramach ekfrazy dzięki fictio personae (i nie tylko) - postaci, które są „jakby żywe"23.

Mozaikę bizantyjska oraz tekst o Łazarzu, poza wykorzystaniem prozopopei w ramach ekfrazy, łączą co najmniej dwie kwestie. Po pierwsze - Teodendron, Teotropia (czyli „bizantyjscy” małżonkowie) i Łazarz nie wypowiadają się , autotematycznie", jako postaci (samo)świadome tego, że są częścią dzieła sztuki, mozaiki, obrazu czy zdjęcia. Po wtóre - i chyba istotniejsze - przemowy tych bohaterów mają apokryficzny charakter i świadczą o apokryficzności tekstów, do których zostały włączone (nie tylko dlatego, że Łazarz jest postacią biblijną): prozopopeja stanowi bowiem jedną z manifestacji apokryficzności niektórych ekfraz.

Hipotezę o przydatności kategorii apokryfu (w rozumieniu zaproponowanym przez Danutę Szajnert ${ }^{24}$ ) w badaniach nad ekfrazą wyprowadzam przede wszystkim $\mathrm{z}$ podobnych $\mathrm{w}$ obydwu formach literackich relacji intertekstualnych łączących tzw. pre-tekst, czyli źródło inspiracji, z pasożytującym na nim utworem. W niektórych ekfrazach bowiem, tak jak w apokryfach, ów pre-tekst ulega reinterpretacji i refokalizacji, uzupełnia się go o to, co wcześniej „ukryte” (i/lub - w przypadku obrazów - niemożliwe do oddania), między innymi właśnie dzięki prozopopei. Pozwala ona bowiem odzyskać pominięte, przemilczane lub traktowane dotychczas marginalnie punkty widzenia ${ }^{25}$ przy jednoczesnym „zachowaniu tzw. realiów wzorca”26, czyli „scenografii”, atmosfery i - w pewnym stopniu - estetyki pre-tekstu (ma ono na celu swojego rodzaju zamaskowanie, przysłonięcie „współczesnego" kontekstu, w którym powstaje taki apokryf), a także (nieuniknionego) uwspółcześnienienia mentalności bohatera (widać to dobrze w przypadku tekstu o Łazarzu, którego ironiczny monolog nie byłby możliwy do wypowiedzenia ani w czasach Sebastiano del Piombo, ani w 'czasach biblijnych'; wiąże się to także ze wspominanymi już emancypacyjnymi własnościami prozopopei).

Bywa jednak, że ożywione dzieło sztuki przemawia na prawach prozopopei, przedstawiając własną - apokryficzną - wersję znanych skądinąd (lub przemilczanych/pominiętych) wydarzeń, niezwiązanych bezpośrednio z tym, co ukazane na obrazie. Jednocześnie rozważania, które można byłoby uznać za „ekfrastyczne”27 nie stanowią głównej części wykorzystującego prozopopeję tekstu. A zatem - mimo że tekst ma apokryficzny charakter, bowiem dzieło sztuki przemawia,

23 Por. V. Cunningham, dz. cyt., s. 61, 70.

24 D. Szajnert, Mutacje apokryfu, w: Genologia dzisiaj, red. W. Bolecki, I. Opacki, IBL PAN, Warszawa 2000, s. 137-157.

25 Zob. D. Szajnert, Dywersyjny potencjał apokryfu, „Zagadnienia Rodzajów Literackich” 2011, z. 2, s. 357-371.

26 D. Szajnert, Mutacje apokryfu..., s. 146.

$27 \mathrm{~Np}$. uwagi dotyczące wyglądu dzieła, kwestie techniczne, ale również dopowiedzenie ewentualnej przedakcji i „poakcji” obrazu - także w postaci informacji o procesie malowania takiego obrazu - czy powiązane z dziełem wypowiedzi krytyczne i rozmaite interpretacje. 
ukazując przemilczany punkt widzenia, a także uzupełniając oficjalną wersję historii i historii sztuki, jego (tekstu) nadrzędnej struktury nie można nazwać ekfrazą (ani nawet np. „formą ekfrastyczną”). Dzieje się tak np. w powieści Portret Pierre’a Assouline’a. Głos zostaje tu oddany namalowanej w 1848 roku przez Jeana-Auguste'a-Dominique’a Ingres’a baronowej Betty de Rothschild, żonie działającego we Francji bankiera Jamesa Mayera Rothschilda. Nieco inaczej niż m.in. w przypadku bohaterów przywoływanych wcześniej tekstów Dehnela i Szymborskiej, Betty zdaje sobie sprawę z tego, że jest tylko przedstawieniem, bohaterką obrazu (w który jej „dusza” wcieliła się w chwili śmierci) i eksponuje swoją sztuczność („Je-

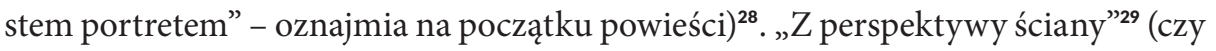
raczej ścian, na których przez niemal 160 lat miała okazję wisieć) opowiada historię swoją i swojej rodziny, wpisaną w najważniejsze wydarzenia schyłku XIX, a także XX i XXI wieku (a zatem, jak chce Valentine Cunningham - zostają tu przywrócone „życie i głos przeszłości”). Historię tę współtworzą wspomnienia baronowej de Rothschild „z czasów życia”, przeplatane rozmowami i sytuacjami, których była świadkiem już jako przedmiot przedstawienia w dziele sztuki (lub też: o których, dzięki tej uprzywilejowanej pozycji, usłyszała). A zatem „zasięg wzroku” obrazu nie musi ograniczać się do weneckiej gondoli sprzed kilkuset lat, jak wyobrażała to sobie cytowana na wstępie Virginia Woolf (zresztą opowieść dzieła sztuki o weneckiej gondoli można by pewnie uznać za ekfrastyczną, odnosiłaby się bowiem do

28 P. Assouline, Portret, przeł. A. Michalska, Noir sur Blanc, Warszawa 2010, s. 12. Choć Portret to najbardziej rozbudowany przykład tego typu tekstu, jaki udało mi się znaleźć, „samoświadomym wypowiedziom prozopopeicznym" poświęca wiele miejsca również Orhan Pamuk w Nazywam się Czerwień. Kontrapunktujące akcję powieści ekfrastyczne prozopopeje odnoszą się do miniatur zdobiących „książki znajdujące się pod koniec XVI wieku w archiwach pałacu Topkapı w Stambule (większość z nich powstała na terenie dzisiejszego Iranu i Afganistanu)". O. Pamuk, Pisarz naiwny i sentymentalny, przeł. T. Kunz, Wydawnictwo Literackie, Warszawa 2012, s. 91. W Nazywam się Czerwień przemawiają postaci, rośliny i zwierzęta z miniatur jako postaci, rośliny i zwierzęta z miniatur. Na przykład personifikacja śmierci: „Jestem śmierć, jak pewnie zdążyliście się zorientować, lecz nie musicie się mnie obawiać - to tylko ilustracja. [...] Podobnie jak bawiące się dzieci, doskonale wiecie, że nie jestem prawdziwa, tymczasem strach ściska wam gardło". O. Pamuk, Nazywam się Czerwień, przeł. D. Chmielowska, Wydawnictwo Literackie, Warszawa 2007, s. 185. Obraz zostaje obdarzony głosem również w Rien ne va plus Andrzeja Barta - w tym przypadku narratorem nie jest jednak faktycznie istniejące malowidło, tylko wymyślony portret fikcyjnego włoskiego arystokraty, Tomasso d'Arcipazziego (A. Bart, Rien ne va plus, WAB, Warszawa 2010). Chwyt najbardziej zbliżony do tego z Portretu zastosował Joseph Heller w powieści Namaluj to (J. Heller, Namaluj to, przeł. I.G. Jackowski, Phantom Press International, Gdańsk 1993). W tym tekście autor obdarzył świadomością, przekonaniami, emocjami i niektórymi zmysłami Arystotelesa z obrazu Rembrandta pt. Arystoteles z popiersiem Homera (1653 r.), choć - co istotne - w tej powieści nie pojawia się pierwszoosobowa narracja namalowanego filozofa, a zatem mamy w niej do czynienia raczej po prostu z personifikacją, nie zaś z prozopopeją. 
rzeczywistości przyległej do tej z reprezentacji malarskiej - zakładając, że „patrzący obraz" byłby np. pejzażem przedstawiającym Wenecję sprzed kilkuset lat albo portretem spoglądającego na Canale Grande Wenecjanina sprzed kilkuset lat). Betty opowiada zatem m.in. o II wojnie światowej, podczas której, jako część kolekcji Rothschildów, zostaje wywieziona z Francji i ukryta w kopalni soli w austriackim Steinbergu wraz z innymi „tworami geniuszu Goi i Ingres'a, Vermeera i Rembrandta”"30. Wspomina także o wojnie francusko-pruskiej („Pewnego dnia Niemcy napadli na Francję i zainstalowali się w Ferrières [jednej z posiadłości Rothschildów]" ${ }^{31}$ ) czy sprawie Dreyfusa, która członków jej rodziny „[...] zupełnie [...] zaskoczyła. Nic jej nie zapowiadało"32. Ta ostatnia wypowiedź jest zresztą zaskakująca, biorąc pod uwagę przejawy zakamuflowanego i otwartego antysemityzmu, o których Betty mówi właściwie już od początku powieści i które nie przestają jej prześladować nawet po śmierci. Jeden $\mathrm{z}$ artykułów prasowych informujących o jej odejściu zostaje bowiem wydrukowany pod tytułem „Wiadomości z getta”, fragment innego brzmi: „[O]to najlepszy dowód, że prasa należy do żydowskiego kapitału. Kiedy umiera baronowa de Rothschild, mówi się jedynie o jej donacjach i dobroczynności" ${ }^{\prime 33}$.

Jednocześnie Betty de Rothschild jest - nawet jako portret - typową, konserwatywną przedstawicielką swojej warstwy społecznej o wyraźnie antydemokratycznych i antyrewolucyjnych poglądach („Demokracja jest synonimem anarchii i chaosu”, „Nie posuwałam się do tego, żeby kazać zamykać okiennice na 14 lipca, lecz gdy zrozumiałam, że w XIX wieku rewolucja tylko się powtarza, nabrałam ochoty, by zmienić swoich współczesnych"34). I - co ciekawe - bywa ksenofobiczna: „[...] czułam się dużo lepiej w okresie Monarchii Lipcowej niż w czasach Drugiego Cesarstwa: dużo przyjemniej być jedną z nielicznych kosmopolitek w na wskroś francuskim towarzystwie, niż być jedną z wielu, gdy triumfujący kosmopolityzm stał się fashionable ${ }^{\text {"35 }}$. Betty pochwala też zresztą konformistyczną reakcję jej dzieci na sprawę Dreyfusa („Rothschildowie tak bardzo zamknęli się w sobie, że omijali temat. Cóż robić, człowiek był niewinny, od początku oskarżano naszą religię, po co dolewać oliwy do ognia" ${ }^{\text {"36) }}$.

W jej opowieści pojawiają się oczywiście również wybitni artyści i politycy m.in. Fryderyk Chopin, „odpychający”37 bracia Goncourt, Honoré de Balzac (Betty uzupełnia oficjalny wizerunek pisarza, zdradzając na przykład, że cały czas zdawała sobie

31 Tamże, s. 114.

32 Tamże, s. 45.

33 Tamże, s. 32-33.

34 Tamże, s. 113-114.

35 Tamże, s. 51.

36 Tamże, s. 46.

37 Tamże, s. 105. 
sprawę z obłudy autora Kobiety porzuconej, który „zawsze [Rothschildami] pogardzał, lecz ze zręcznością dworzanina niczego nie dawał po sobie poznać"38), a także Heinrich Heine czy Nicholas Changarnier (z którymi z kolei romansowała).

Ożywienie Betty de Rothschild w powieści Assouline’a nie ogranicza się jednak wyłącznie do obdarzenia jej głosem i umiejętnością obserwacji. W ramach refokalizacji - zmiany perspektywy i umożliwienia prowadzenia narracji, zmiany statusu przedmiotu oglądanego na status podmiotu oglądającego i mówiącego ${ }^{39}$ - zachodzi tutaj niemal całkowita re-sensualizacja ${ }^{40}$ : sportretowana baronowa miewa bowiem ataki migreny, wstydzi się, płacze czy odczuwa zimno. Zbiera się jej również np. na kaszel od dymu z cygara Hermanna Göringa oglądającego ją przed wywiezieniem z Francji. Granice tego "chwytu formalnego" (jak nazywa prozopopeiczne ożywienie obrazu narratorka $\mathrm{w}$ jednym $\mathrm{z}$ autotematycznych wtrętó $\mathrm{w}^{41}$ ) zostają niekiedy w powieści ryzykownie przesunięte. $\mathrm{W}$ trakcie opisywania swoich losów podczas II wojny światowej, Betty zestawia losy wywożonych ludzi i dzieł sztuki, nazywając muzeum Jeu de Paume (miejsce, z którego odjeżdżają i do którego wracają rozkradzione paryskie zbiory) kolejno „Drancy obrazów” i „naszą «Lutetią»"

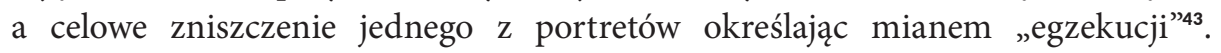

38 Tamże, s. 63.

39 Szerzej o refokalizacji w literackich apokryfach pisałam w tekście Refocalization as a Strategy of Apocryphal Rewriting, „Zagadnienia Rodzajów Literackich” 2016, z. 1, s. 63-79.

40 Po ten termin w badaniach nad ekfrazą sięga Anna Estera Mrozewicz, korzystająca z ustaleń Maurice'a Merleau-Ponty'ego oraz W.J.T. Mitchella, którzy dowartościowują rolę zmysłów innych niż zmysł wzroku w postrzeganiu obiektów wizualnych. Badaczka w analizowanych tekstach ekfrastycznych odnajduje „pragnienie wyjścia poza to, co poznawalne jedynie zmysłem wzroku”, co sytuuje te teksty „niejako po stronie "antyokulocentryzmu«” (A.E. Mrozewicz, Śladami ekfrazy. Duńscy pisarze współcześni wobec sztuk wizualnych, Wydawnictwo Poznańskie, Poznań 2010, s. 301). W związku z tym nie sposób nie zauważyć, że rekontekstualizując w zaproponowany sposób „re-sensualizację”, dokonuję nadużycia; wynika to jednak z operatywności, którą w moim przekonaniu odznacza się termin odnaleziony/zaproponowany przez Mrozewicz. Być może dałoby się go powiązać również z zaproponowaną przez Magdalenę Rembowską-Płuciennik „fokalizacją zmysłową” (skupienia się podmiotu mówiącego na konkretnym zmyśle silniej niż na pozostałych, co ujawnia się w trakcie narracji za pośrednictwem stosownych określeń). Zob. M. Rembowska-Płuciennik, W cudzej skórze. Fokalizacja zmysłowa a literackie reprezentacje doświadczeń sensualnych, w: Literackie reprezentacje doświadczenia, red. W. Bolecki, E. Nawrocka, IBL PAN, Warszawa 2007, s. 51-67.

41 Zob. P. Assouline, dz. cyt., s. 18.

42 Tamże, s. 137 i s. 154. Do obozu w Drancy przewożono zachodnioeuropejskich Żydów przed transportem do Auschwitz-Birkenau, natomiast w paryskim hotelu Lutetia tuż po wojnie znajdowali schronienie więźniowie wojenni i ludzie wracający z obozów koncentracyjnych. Zob. Nazi Transit Camps: Drancy, https://www.jewishvirtuallibrary.org/drancy-transit-camp [dostęp 3.09.2018].

43 P. Assouline, dz. cyt., s. 155. 
Jednocześnie narratorka zauważa, że niemieccy konserwatorzy obchodzą się z nią „Z największą delikatnością” („Zapewne niewiele jest teraz Żydówek, które Niemcy tak traktują" ${ }^{\text {"44) }}$.

To wielostronne ożywienie (wraz z jego wyjaskrawionymi przejawami) można powiązać ze specyfiką portretu malarskiego, który zakłada w pewnym stopniu tożsamość reprezentowanego podmiotu i przedmiotu reprezentacji. Podobnie jak fotografia (choć jednak w mniejszym stopniu niż ona) konterfekt ma bowiem status „[...] dokumentu, indeksu: śladu dawnego świata, nieżyjących już osób”45. W Portrecie Assouline’a wielokrotnie podkreśla się cienką granicę między rzeczywistą, żyjącą niegdyś (i wciąż przez niektórych pamiętaną) osobą, a przedmiotem przedstawienia w dziele sztuki: „ «Tylko ostrożnie z babcią!» żartuje Guy za każdym razem, gdy ktoś podchodzi do mnie zbyt blisko. Trudno zgadnąć, czy chodzi mu o ikonę Rothschildów, obdarzoną wielką siłą symboliczną, czy też o portret Ingres’a, uważany za jeden z najbardziej udanych"46.

Jednocześnie wydaje się, że w „kontakcie” właśnie z portretem najłatwiej jest doświadczyć aury dzieła sztuki, o której Walter Benjamin pisał w ten oto, między innymi, sposób:

Doświadczenie aury zasadza się na przeniesieniu potocznej w społeczeństwie ludzkim formy reakcji na stosunek nieożywionego czy natury do człowieka. Obserwowany czy też taki, kto za obserwowanego się uważa, otwiera spojrzenie. Doświadczyć aury zjawiska oznacza użyczyć jej zdolności otwierania spojrzenia ${ }^{47}$.

Można by zatem zaryzykować twierdzenie, że powieść Assouline’a stanowi próbę zwerbalizowania doświadczenia aury dzieła Ingres’a. Wydaje się zresztą, że ta kwestia jest w Portrecie ciekawie sproblematyzowana. Narratorka zauważa bowiem, że do odkrycia jej (jako obrazu) w pełni „nie wystarczy największa przenikliwość, wyjątkowa pamięć ikonograficzna czy najwspanialsza erudycja. Do tego trzeba zdolności empatycznych [...]"48. Jednocześnie sportretowana baronowa spotyka się ze skrajnymi przypadkami prób doznania aury (dowodzą one

44 Tamże, s. 145.

45 D. Lisak-Gębala, Ultraliteratura, s. 51.

46 P. Assouline, dz. cyt., s. 159.

47 W. Benjamin, O kilku motywach u Baudelaire'a, w: tegoż, Twórca jako wytwórca. Eseje i rozprawy, przeł. R. Reszke, Wydawnictwo KR, Warszawa 2011, s. 166.

48 Assouline wydaje się tu podzielać stanowisko Zbigniewa Herberta i Gustawa Herlinga-Grudzińskiego krytyczne wobec wyspecjalizowanego, profesjonalnego oglądu dzieł sztuki. Zob. J. Bielska-Krawczyk, Między widzialnym a niewidzialnym. Twórczość Gustawa Herlinga-Grudzińskiego, Universitas, Kraków 2004; M. Śniedziewska, „Mali mistrzowie” Zbigniewa Herberta - próba rekonstrukcji, w: tejże, Siedemnastowieczne malarstwo holenderskie w literaturze polskiej po 1918 roku, Wydawnictwo Naukowe Uniwersytetu Mikołaja Kopernika, Toruń 2014. 
zresztą raczej braku „zdolności empatycznych”): „Od stu lat zdarza mi się czuć na sobie przeszywający męski wzrok i wiem, że może kryć głęboką zniewagę, płynącą z najśmielszych fantazji wobec portretu kobiety"an.

Co ciekawe, owo zwerbalizowanie doświadczenia aury dzieła Ingres’a zostaje w Portrecie powiązane z ogólną refleksją na temat stylów odbioru literatury (i sztuki). We wspomnianym już autotematycznym wtręcie narratorka zauważa bowiem: „Zdumiewa, że pisarze częściej nie wpadali na pomysł, by obdarzyć głosem jakieś arcydzieło malarstwa, gdy się pomyśli, czego taki obraz nieraz bywa świadkiem [...]. Tylko specjaliści zobaczą w tym chwyt formalny. A czytelnik? Może usłyszy bicie serca, gdy przyłoży ucho do mojego portretu?"50.

Należy jeszcze dodać, że choć - jak pisałam - znaczną część utworu Pierre’a Assouline’a stanowi historia Betty i jej rodziny powiązana z najważniejszymi wydarzeniami ostatnich (niemal) dwustu lat, powieść wieńczy rozbudowana (auto) ekfraza tytułowego portretu narratorki i zarazem bohaterki. Współtworzą tę ekfrazę różnorodne elementy, które mogły zostać logicznie połączone i włączone do tekstu dzięki zastosowaniu prozopopei. Wydaje się zatem, że Portret to przykład twórczego pasożytowania tekstu na obrazie, znajdujący się na przeciwległym biegunie w stosunku do tych przywoływanych na początku artykułu. To nie ekfraza umożliwia prozopopeję (prozopopeja nie jest efektem działań ekfrastycznych), ale - w pewnym sensie - prozopopeja ekfrazę. Powieściowa deskrypcja dzieła sztuki rozpoczyna się, kiedy portret baronowej de Rothschild zostaje wysłany na „tournée" po światowych muzeach (m.in. National Gallery w Londynie czy National Gallery of Art w Waszyngtonie), z dłuższym przystankiem w Luwrze. Podobnie jak w przypadku rozdziałów (auto)biograficzno-historycznych, na rozbudowaną ekfrazę składają się i wspomnienia Betty, i komentarze usłyszane już w muzeach. Sportretowana baronowa opowiada zatem przede wszystkim o okolicznościach powstania obrazu, m.in. apokryficznie podważając obiegowe opinie („Chodziły słuchy, że Ingres bardzo zabiegał o prawo namalowania mojego portretu. Było wprost przeciwnie" ${ }^{\prime 1}$, „[...] niektórzy twierdzili, że Ingres porwał mnie z sali balowej, pociągnął za rękę i kazał pozować [...]. Naprawdę zaś seanse odbywały się w buduarze u nas przy Laffitte, lecz Ingres nie wyprowadzał ludzi z błędu"52) czy też zdradzając tajniki warsztatu mistrza: „Bał się zabrać do mojej głowy, musiał

49 P. Assouline, dz. cyt., 174.

50 Tamże, s. 18. Być może jako swoiste uzupełnienie tej wypowiedzi można potraktować następujące rozpoznanie Magdaleny Rembowskiej-Płuciennik: „Perspektywa narracyjna [na płaszczyźnie bohater-czytelnik] ma znaczenie dla odbioru pojętego jako żywe doświadczenie o psychocielesnym podłożu, któremu taki kształt nadaje specyfika naszej świadomości". M. Rembowska-Płuciennik, Poetyka intersubiektywności: Kognitywistyczna teoria narracji a proza XX wieku, Wydawnictwo Naukowe Uniwersytetu Mikołaja Kopernika, Toruń 2012, s. 22.

51 P. Assouline, dz. cyt., s. 160.

52 Tamże, s. 174. 
najpierw nauczyć się na pamięć twarzy, przeniknąć jej tajemnicę, zanim porwał się na malowanie oczu"53. Te wypowiedzi uzupełniają ogólne rozpoznania dotyczace malarstwa portretowego Ingres’a („Po wielkim artyście spodziewamy się, że nie zadowoli się oddaniem pozornego podobieństwa, lecz uchwyci w twarzy to, co jest niezmienne”54). Narratorka opisuje także detale już namalowanego obrazu („Ingres zrobił [...] na papierze subtelne szkice mojej ręki z widoczną długą linią życia"55, „Ileż wirtuozerii w zmięciu satynowych kokard, spiętrzeniu bufiastej spódnicy, kompozycji podwójnej koronkowej berty!"56).

Najbardziej interesujący (i chyba najobszerniejszy) komponent ekfrazy stanowią jednak uwagi dotyczące recepcji portretu. Narratorka przywołuje bowiem zarówno komentarze usłyszane jeszcze za życia, jak i już po śmierci. W obu przypadkach są to wypowiedzi profesjonalnych krytyków sztuki oraz zwykłych odbiorców. Wśród komentujących obraz można zatem odnaleźć nie tylko francuskich dziewiętnastowiecznych pisarzy, krytyków i historyków sztuki (takich jak np. Louis Geoffroy czy Charles Blanc), lecz również współczesnych badaczy, np. Daniela Arasse’a i Aileen Ribeiro, amerykańskiej historyk mody, której opinia przypada baronowej „do gustu” („Pani de Rothschild” - mówi Ribeiro - „podobnie jak pani de Senonnes sytuuje się na marginesie klasycznej arystokracji. Swoimi pozami obie manifestują otwarcie seksualność [...]"57; Betty oczywiście uzupełnia tę uwagę: „Trzeba dodać, że rozkoszna pani de Senonnes ośmieliła całe pokolenie admiratorów, którzy walnie przyczynili się do jej reputacji kobiety zmysłowej" ${ }^{58}$ ). Narratorka zestawia ze sobą zresztą wypowiedzi krytyków oraz „zwykłych” oglądających z czasów Drugiej Republiki i współczesnych („Na przykład ten Amerykanin w hawajskiej koszuli [...], mówi dokładnie to samo, co wicehrabia de Beaumont-Vassy [...]. I jeden, i drugi uznał, że całość jest cudownie harmo-

53 Tamże, s. 161.

54 Tamże, s. 162.

55 Tamże, s. 161. Tę wypowiedź można powiązać z rozpoznaniem Roberta de la Sizeranne, pisarza i krytyka sztuki żyjącego na przełomie XIX i XX wieku: „Ale to, co [Ingres] najbardziej lubi, co z największym zapałem podziwia, to pokazuje takim, jak jest. Na przykład ręce. Istotnie studiuje ręce swoich modeli z namiętną ciekawością, niemal lubieżnie. Bada je równie wnikliwie jak chiromantka. Toteż nie są one tak jednakowe jak ręce na portretach Van Dycka i wielu innych; na ich podstawie można by zidentyfikować twarze" (R. de la Sizeranne, Oko i ręka pana Ingres, w: Ingres w oczach własnych i w oczach przyjaciół, oprac. P. Courthion, przeł. E. Bąkowska, Państwowy Instytut Wydawniczy, Warszawa 1969, s. 270).

56 P. Assouline, dz. cyt., s. 166.

57 Tamże, s. 173. Warto zaznaczyć, że do swej powieści Pierre Assouline dołączył obszerną bibliografię dotyczącą dzieł Ingres'a, Rothschildów i czasów, których Portret dotyczy - wypowiedzi krytyków i historyków sztuki o obrazie przedstawiającym Betty można zatem zlokalizować. Zob. P. Assouline, dz. cyt., s. 195-199. 
nijna, nawet jeśli uderza [...] zestrojenie czereśniowego odcienia sukni z kanapą w kolorze bordo" $\left.{ }^{\prime 59}\right)$. Niezwykle ciekawie wypadają w tym względzie uwagi Louisa Geoffroy’a skonfrontowane z rozpoznaniem feministycznej historyczki sztuki Carol Ockman. Jak zauważa narratorka, Geoffroy

był raczej pod wrażeniem obrazu. Dlaczego jednak - zastanawia się Betty - za każdym razem, gdy [...] napomykał o dziwnie «orientalnym» nastroju, widocznym zwłaszcza w zarysie brwi, ja słyszałam raczej «semicki»? Bez wątpienia uważał mnie za kwintesencję Żydów i Rothschildów, postać biblijną, która wymknęła się ze scen tureckich samego Ingres’a, z Toalety Estery Chassériau czy też z Kobiet algierskich Delacroix ${ }^{60}$.

Ockman stojąc przed obrazem, mówi natomiast: „Portret jest zachwycający, ale jednocześnie to stereotypowe wyobrażenie egzotycznej i zmysłowej Żydówki”‘1. Zestawienie tych dwóch opinii wyrażonych przez dwoje ludzi o - wydaje się - krańcowo różnych światopoglądach, pozwala wyeksponować niezmienną ${ }^{62}$ „kulturowość” spojrzenia. Jak pisał Ryszard Nycz: „Widzimy to, co spodziewamy się zobaczyć, wiedza [oraz - chciałoby się dodać - uświadomione i nieuświadomione uprzedzenia, JD] warunkuje (wyprzedza, umożliwia, ogranicza) identyfikację postrzeganego"ø3. Jednocześnie, niezależnie od tego, czy nieświadomie szuka się w oglądanym przedmiocie potwierdzenia własnych przedsądów, czy też dostrzega w nim wyłącznie stereotyp, w tym samym stopniu pomija się jednostkowość takiego przedmiotu (w tym przypadku dzieła sztuki), nie dba się o jego „aurę”.

Zestawienie uwag Geoffroya i Ockman pozwala jednak również zaobserwować zmienność kulturowego spojrzenia. To Betty dostrzega tożsamość opinii obojga znawców, ale w rzeczywistości są one zupełnie odmienne. Geoffroy i Ockman pozornie mówią to samo, przypisując wizerunkowi baronowej de Rothschild określone stereotypowe cechy związane z jej pochodzeniem, jednakże sens tych wypowiedzi różni się ze względu na inne zaplecze kulturowe obojga patrzących. Krytyk nie jest świadomy swojego ograniczającego i oceniającego spojrzenia, którym obdarza postać Betty, natomiast w uwadze Ockman można rozpoznać dystans, z jakim odnosi się ona do nieakceptowanej przez siebie konwencji portretowania Żydówek: a zatem krytyce zostaje tu poddany właściwie Ingres i jego sposób malowania, nie zaś bohaterka obrazu.

59 Tamże, s. 176.

60 Tamże, s. 163.

61 Tamże, s. 176.

62 Betty de Rothschild zastanawia się nawet: „czyżby spojrzenie i osądy ewoluowały mniej niż sądzimy?". Tamże, s. 176.

63 R. Nycz, Poetyka doświadczenia. Teoria - nowoczesność - literatura, IBL PAN, Warszawa 2012, s. 28. 
Mimo wszystko wydaje się, że zarówno w przypadkach, w których prozopopeja jest efektem ekfrazy, jak i wtedy, gdy ekfraza zostaje wprowadzona dzięki prozopopei, teksty literackie „ożywiające” dzieła sztuki można uznać za kolejne subtelne próby zaktualizowania mitu Pigmaliona.

Wydaje się również, że wbrew temu, co pisała Virginia Woolf, obrazy nie wiszą na ścianach, „jakby upływ wieków nie miał dla nich znaczenia”: w przypadku Portretu to właśnie refleksja nad historią oraz apokryficzna opowieść o niej stanowi najważniejszy cel obdarzenia obrazu świadomością, „upływ wieków” ma dla Betty de Rothschild ogromne znaczenie. Do namysłu nad dziejami prowokuje długowieczność bohaterki-obrazu, zaufanie czy raczej specyficzna obojętność, jaką wzbudza, jako pozornie nieżywotna, a także - przede wszystkim? - usytuowanie jej między „rzeczywistością” i fikcją. "Spoglądając w głąb pokoju”64, namalowana baronowa nie ogranicza swojego pola widzenia do czasów i warunków, w których została stworzona, ale z pewnym pobłażaniem przygląda się kolejnym pokoleniom śmiertelników.

W Portrecie owo usytuowanie między fikcją i „rzeczywistością” umożliwia specyficzna refokalizacja: postać z obrazu „patrzy” i „czuje”, natomiast malarska „czwarta ściana” zostaje zburzona. Bohaterka przedstawienia zdaje sobie sprawę ze swej materialności i dwuwymiarowości, ale właśnie dzięki temu jest w stanie przyglądać się swemu otoczeniu z dystansem: kierunek jej spojrzenia zostaje skierowany „zewnątrz”, ku „rzeczywistości”. Powieściowa Betty jest ekfrastycznie opowiada o swoim malarskim wizerunku i etapach pracy nad przedstawiającym ją obrazem, choć rama, w której została zamknięta nie zostaje poszerzona. Uniwersum, do którego odnosi się bohaterka, to bowiem nie uniwersum dzieła sztuki, tylko „rzeczywisty świat”, który obserwuje ze ścian pokoju czy muzeum. Niewątpliwie ma to również związek z gatunkiem malarskim, który reprezentuje malowidło. Portret, choć statyczny, jest w stanie wyzwolić narrację, ale to, że przedstawia jedną, rzeczywistą, powszechnie znaną osobę, której „autobiografia” jest potencjalnie interesująca, prowokuje autora do dopisania specyficznego monologu sytuującego się na pograniczu zmyślenia i opowieści o „prawdziwych”, historycznych wydarzeniach i ludziach.

\section{Bibliografia}

Assouline Pierre, Le Portrait, Éditions Gallimard, Paris 2007.

Assouline Pierre, Portret, przeł. Anna Michalska, Noir sur Blanc, Warszawa 2010.

Bart Andrzej, Rien ne va plus, WAB, Warszawa 2010.

Bartol Krystyna, Poezja - malarstwo. Plutarch o stynnym powiedzeniu Simonidesa, „Roczniki Humanistyczne” 2006-2007, z. 3, s. 107-118.

64 W. Woolf, dz. cyt., s. 193. 
Bartsch Shadi, Elsner Jaś, Eight Ways of Looking at an Ekphrasis, „Classical Philology" $2007 \mathrm{nr} 1$, s. ii.

Benjamin Walter, O kilku motywach u Baudelaire'a, w: Walter Benjamin, Twórca jako wytwórca. Eseje i rozprawy, przeł. Robert Reszke, Wydawnictwo KR, Warszawa 2011, s. 133-170.

Bielska-Krawczyk Joanna, Między widzialnym a niewidzialnym. Twórczość Gustawa Herlinga-Grudzińskiego, Universitas, Kraków 2004.

Collins Christopher, Reading the Written Image. Verbal Play, Interpretation and the Roots of Iconophobia, The Pennsylvania State University Press, Pennsylvania 1991.

Cunningham Valentine, Why Ekphrasis?, „Classical Philology” 2007, nr 1, s. 57-71.

Czermińska Małgorzata, Ekfrazy w poezji Wisławy Szymborskiej, „Teksty Drugie” 2003, nr 2-3, s. 230-242.

Dynkowska Julia, Refocalization as a Strategy of Apocryphal Rewriting, „Zagadnienia Rodzajów Literackich" 2016, z. 1, s. 63-79.

Gogler Paweł, Kłopoty z ekfraza, „Przestrzenie Teorii” 2004, z. 3-4, s. 137-152.

Gorzkowski Albert, „Ut pictura verba”: zagadnienie unaocznienia w retoryce starożytnej i wczesnonowożytnej, „Pamiętnik Literacki” 2001, nr 92/2, s. 37-59.

Hagstrum Jean Howard, The Sister Arts: The Tradition of Literary Pictorialism and English Poetry From Dryden to Gray, University of Chicago Press, Chicago 1958.

Heffernan James A. W., Ekphrasis and Representation, „New Literary History” 1991, nr 2, s. 297-316.

Heller Joseph, Namaluj to, przeł. Iwo Gabriel Jackowski, Phantom Press International, Gdańsk 1993.

Lausberg Heinrich, Retoryka literacka. Podstawy wiedzy o literaturze, przeł. oprac. i wstęp Albert Gorzkowski, Homo Homini, Bydgoszcz 2002.

Lisak-Gębala Dobrawa, Ultraliteratura. O strategiach transmedialnych i poszukiwaniu pozawerbalnego we wspótczesnej literaturze polskiej, Universitas, Kraków 2014.

Lisak-Gębala Dobrawa, Wizualne odskocznie. Wokół współczesnej eseistyki o malarstwie i fotografii, Universitas, Kraków 2016.

Man de Paul, Autobiografia jako odtwarzanie, przeł. Maria Bożena Fedewicz, „Pamiętnik Literacki” 1986, z. 2, s. 307-318.

Mrozewicz Anna Estera, Śladami ekfrazy. Duńscy pisarze wspótcześni wobec sztuk wizualnych, Wydawnictwo Poznańskie, Poznań 2010.

Nazi Transit Camps: Drancy, https://www.jewishvirtuallibrary.org/drancy-transitcamp [dostęp 3.09.2018].

Nycz Ryszard, Poetyka doświadczenia. Teoria - nowoczesność - literatura, IBL PAN, Warszawa 2012.

Pamuk Orhan, Nazywam się Czerwień, przeł. Danuta Chmielowska, Wydawnictwo Literackie, Warszawa 2007. 
Pamuk Orhan, Pisarz naiwny i sentymentalny, przeł. Tomasz Kunz, Wydawnictwo Literackie, Warszawa 2012.

Popowski Remigiusz, Starożytny przewodnik po neapolitańskiej pinakotece, w: Filostrat Starszy, Obrazy, przeł. i wstęp Remigiusz Popowski, Prószyński i S-ka, Warszawa 2004, s. 14-97.

Progymnasmata. Greckie ćwiczenia retoryczne i ich modelowe opracowanie, oprac., przeł. i koment. Henryk Podbielski, Towarzystwo Naukowe Katolickiego Uniwersytetu Lubelskiego Jana Pawła II, Lublin 2013.

Rembowska-Płuciennik Magdalena, Poetyka intersubiektywności: kognitywistyczna teoria narracji a proza XX wieku, Wydawnictwo Naukowe Uniwersytetu Mikołaja Kopernika, Toruń 2012.

Rembowska-Płuciennik Magdalena, W cudzej skórze. Fokalizacja zmysłowa a literackie reprezentacje doświadczeń sensualnych, w: Literackie reprezentacje doświadczenia, red. Włodzimierz Bolecki, Ewa Nawrocka, IBL PAN, Warszawa 2007, s. 51-67.

Sizeranne de la Robert, Oko i ręka pana Ingres, w: Ingres w oczach własnych i w oczach przyjaciót, oprac. Pierre Courthion, przeł. Eligia Bąkowska, Państwowy Instytut Wydawniczy, Warszawa 1969, s. 259-281.

Swoboda Bartosz, Ekfrazy modernistyczne i „mowa dzieła sztuki”, „Slovo. Journal of Slavic Languages, Literatures and Cultures” 2015, nr 56, s. 90-104.

Szajnert Danuta, Dywersyjny potencjat apokryfu, „Zagadnienia Rodzajów Literackich" 2011, z. 2, s. 357-371.

Szajnert Danuta, Mutacje apokryfu, w: Genologia dzisiaj, red. Włodzimierz Bolecki, Ireneusz Opacki, IBL PAN, Warszawa 2000, s. 137-157.

Śniedziewska Magdalena, „Mali mistrzowie” Zbigniewa Herberta - próba rekonstrukcji, w: Magdalena Śniedziewska, Siedemnastowieczne malarstwo holenderskie w literaturze polskiej po 1918 roku, Wydawnictwo Naukowe Uniwersytetu Mikołaja Kopernika, Toruń 2014.

Tomczok Marta, Prozopopeja, w: Ilustrowany słownik terminów literackich. Historia, anegdota, etymologia, red. Zbigniew Kadłubka, Beata Mytych-Forajter i Aleksander Nawareckiego, Słowo/Obraz Terytoria, Gdańsk 2018, s. 393-394.

Webb Ruth, Ekphrasis Ancient and the Modern: The Invention of a Genre, „Word and Image" 1999, t. 15, nr 1, s. 7-18.

Woolf Virginia, Obrazy i portrety, w: Virginia Woolf, Eseje wybrane, przeł. Magdalena Heydel, Karakter, Kraków 2015, s. 193-198. 
Julia Dynkowska

\title{
" On croirait qu'elle va parler " est le lieu commun?" Ambiguous relations between prosopopoeia and ekphrasis
}

\author{
Summary
}

It stands to reason that ekphrasis cannot be limited to the detailed but plain description of the artifact, for it often concerns what is not there in the painting as well. Authors of the ekphrases sometimes "animate" or "revive" a work of art, which manifests itself in narrativization of painted scenes. The process is also frequently supplemented by its continuation or backstory and fictitious utterances of figures depicted in the painting. The paper discusses a specific literary form of that kind of "animation", that is texts in which characters that can be seen in a painting (or paintings itself) receive the voice through the prosopopoeia and expose their selfawareness of "artificiality". The precise subject of this study is P. Assouline's novel Le Portrait which is narrated by baroness Betty de Rothschild, the figure from the J.A.D. Ingres' painting. In this article, I am focusing on the mode and meaning of prosopopoeia in Assouline's novel. I am also trying to examine whether every text that is based on the concept of a "speaking" work of art (i.e. in which prosopopoeia is used) can be described as ekphrasis.

Keywords: intertextuality, intersemiotics, prosopopoeia, ekphrasis, apocryphon, art, Jean-Auguste-Dominique Ingres, Pierre Assouline

Julia Dynkowska - dr, pracuje w Katedrze Teorii Literatury Instytutu Kultury Współczesnej Uniwersytetu Łódzkiego. Interesuje się literaturą w pespektywie kulturowej oraz intertekstualnością - zwłaszcza apokryficznością oraz związkami literatury z innymi dziedzinami sztuki. Artykuły na te tematy publikowała m.in. w „Zagadnieniach Rodzajów Literackich” i tomach zbiorowych. Autorka rozprawy doktorskiej na temat powiązań ekfrazy i apokryfu.

(c) by the author, licensee Łódź University - Łódź University Press, Łódź, Poland. This article is an open access article distributed under the terms and conditions of the Creative Commons Attribution license CC-BY-NC-ND 4.0 (https://creativecommons.org/licenses/by-nc-nd/4.0/)

Received: 15.09.2018; verified: 5.09.2019 Accepted: 15.09.2019. 